\title{
FAKTOR YANG MEMPENGARUHI PERANAN KELOMPOK SIAGA BENCANA UNTUK MEWUJUDKAN KESIAPSIAGAAN MASYARAKAT DI KOTA PADANG
}

\author{
Muhardina Jelita \\ Jurusan Administrasi Publik, Fakultas Ilmu Sosial, Universitas Negeri Padang \\ mujelita95@gmail.com \\ Zikri Alhadi \\ Jurusan Administrasi Publik, Fakultas Ilmu Sosial, Universitas Negeri Padang \\ ianunpzikri@yahoo.co.id
}

\begin{abstract}
North Padang Subdistrict is a region that is often hit by floods and coastal abrasions, and is a red zone in the earthquake and tsunami disaster. This study discusses the factors that influence the role of the disaster preparedness group during pre-disaster to realize the preparedness of the community in Padang Utara Sub-District. This research uses descriptive qualitative research. Methods in collecting data through interviews and documentation studies. In determining informants using purposive and incidental techniques. The results of this study indicate that disaster preparedness groups in carrying out their roles during pre-disaster are influenced by several factors. Factors that encourage the Disaster Alert Group to play a role are the geographical conditions of the northern Padang sub-districts that are prone to disasters, the existence of programs from the regional government for disaster risk reduction, and the existence of a social humanitarian spirit possessed by members of the Disaster Alert Group. Meanwhile, the inhibiting factor is the absence of operational funds for activities owned by the Disaster Preparedness Group, the absence of facilities and infrastructure for supporting activities, the condition of members who are partly indifferent, and the conditions of the community in the area.
\end{abstract}

\section{Keywords: Disaster Preparedness Group, Preparedness, Society}

\section{abstrak}

Kecamatan Padang Utara merupakan daearah yang sering dilanda bencana banjir dan abrasi pantai, serta merupakan daerah zona merah bencana gempa bumi dan tsunami. Penelitian ini membahas tentang faktor yang mempengaruhi peranan Kelompok siaga bencana pada saat pra bencana untuk mewujudkan kesiapsaigaan masyarakat di Kecamatan Padang Utara. Penelitian ini menggunakan jenis penelitian kulaitatif deskriptif. Metode dalam pengumpulan data melalui wawancara dan studi dokumentasi. Dalam menentukan informan menggunakan teknik purposive dan insidental. Hasil dari penelitian ini menunjukkan bahwa kelompok siaga bencana dalam menjalankan perannya pada saat pra bencana dipengaruhi oleh beberapa faktor. Faktor yang mendorong Kelompok Siaga Bencana berperan adalah kondisi geografis wilayah kecamatan padang utara yang rawan terhadap bencana, adanya program dari pemerintah daerah untuk pengurangan risiko bencana, serta adanya jiwa sosial kemanusiaan yang dimiliki oleh anggota Kelompok Siaga Bencana. Sementara itu, yang menjadi faktor penghambatnya adalah tidak adanya dana operasional kegiatan yang dimiliki oleh Kelompk Siaga Bencana, tidak adanya sarana dan prasarana penujang kegiatan, kondisi anggota ada yang sebagian tidak peduli, dan kondisi masyarakat yang ada di wilayah tersebut.

Kata Kunci : Kelompok Siaga Bencana, Kesiapsiagaan, Masyarakat 


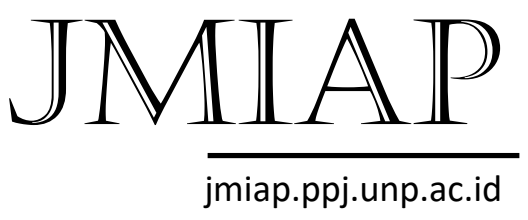

\section{Pendahuluan}

Berbagai jenis bencana sering melanda wilayah Indonesia. Hal ini dikarenakan wilayah Indonesia menjadi titik persimpangan tektonik aktif yakitu lempeng Indo-Australia dibagian selatan, lempeng Eurasia di bagian utara, dan Lempeng Pasifik di bagian timur. Kota Padang sebagai salah satu kota Indonesia yang berada di Provinsi Sumater. Barat merupakan kota yang memiliki risiko bencana sangat tinggi. Kecamatan Padang Utara merupakan salah satu wilayah yang berada di Kota Padang dan merupaka salah satu Zona Merah terjadi nya bencana terutama gempa bumi dan Tsunami. (Dokumen Recana Kontijensi Tsunami Kota Padang 2017). Dalam Dokumen Rencana Kontijensi Tsunami tersebut terdapat 50 Kelurahan yang terpapar zona merah termasuk 7 (tujuh) kelurahan yang berada di kecamatan Padang Utara. Kemudian, penelitian Oktari dan Manurung (2010) menjelaskan bahwa secara sederhana zona rawan tsunami di kota Padang terbagi ke dalam tiga zona yakni hight risk zone (daerah dengan tingkat kerentanan tinggi terhadap tsunami) yaitu kecamatan Padang Timur, Padang Utara, Nanggalo, sebagian Kota Kecamatan Koto Tangah. Medium risk zone (daerah dengan tingkat kerentanan menengah terhadap tsunami) yaitu kecamatan Padang Timur, Padang Selatan, Kuranji, Bungus Teluk Kabung. Low risk zone (daerah dengan tingkat kerentanan rendah terhadap tsunami) yaitu kecamtan Lubuk Kilangan, Kecamatan, Pauh, sebagian Kota Kecamatan Koto Tangah. Selain Tsunami, bencana yang juga sangat rawan terjadi di Kecamatan Padang Utara adalah banjir dan abrasi pantai.
JURNAL ILMU ADMINISTRASI PUBLIK

Email : jianfis.unp@gmail.com Vol. 1 No. 1 Tahun 2018
Terjadinya Gempa berkekuatan 7,6 SR yang mengguncang Sumatera Barat pada tahun 2009 memakan korban jiwa lebih dari 1.100 orang, kerugian yang dialami mencapai Rp21,6 triliun. Daearah yang paling parah terkena dampaknya adalah Kota Padang, Kota Pariaman, dan Kab. Padang Pariaman. Sekitar 115.000 rumah hancur dan lebih dari 135.000 rumah rusak. Bencana gempa ini memberikan dampak negatif kepada masyarakat diantaranya yaitu mengacaukan ribuan usaha kecil dan menengah sementara kerugian yang dialami oleh perusahanperusahaan besar relatif lebih kecil. Kemudian lahan pekerjaan cenderung terbatas karena lahan perkerjaan yang terkonsentrasi di daerah terdampak. Proses pemulihan pasca gempa dperlukan biaya sebesar Rp 23 triliun. Oleh karena itu diperlukan upaya-upaya peningkatan kesiapan untuk menghadapi bencana di masa yang akan datang salah satu upaya nya dengan melakukan kegiatan pengurangan risiko bencana (WorldBank Group, 2009).

Penelitian Hidayati (2008) menyimpulkan bahwa mayarakat di sebagian besar Kabupaten/Kota masih kurang siap dalam mengantisipasi bencana gempa bumi dan tsunami, pahadal wilayah Indonesia berada di daerah rawan bencana. Sehingga adanya kesiapsiagaan masyarakat untuk mengurangi bencana menjadi hal yang sangat penting dalam pengelolaan bencana. Kemudian Penelitian Alhadi dan Sasmita (2014) menjelaskan bahwa upaya yang dapat dilakukan dalam meningkatkan kesiapsiagaan masyarakat adalah dengan menggunakan metode-metode yang berbasis kearifan lokal masyarakat. Kesiapsiagaan masyarakat memerlukan peran aktif dari masyarakat. Salah satu bentuk partisipasi paling kecil adalah 


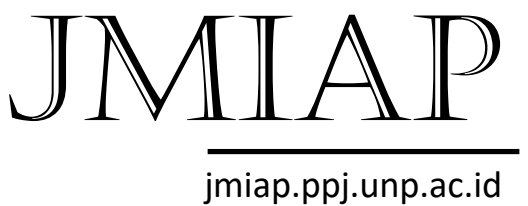

jmiap.ppj.unp.ac.id
JURNAL ILMU ADMINISTRASI PUBLIK

Email : jianfis.unp@gmail.com Vol. 1 No. 1 Tahun 2018 kesiapsiagaan diri dan keluarga masingmasing, sementara pada lingkungan yang lebih luas mencakup komunitas kelompok atau kelompok-kelompok masyarakat. Oleh karena itu dalam masyarakat menjadi suatu keharusan menbentuk Kelompok Siaga Bencana. Kelompok Siaga Bencana adalah kelompok di tingkat desa yang menjadi pelopor atau penggerak kegiatan pengurangan risiko bencana. Pengurangan risiko bencana berbasis masyarakat adalah proses pengelolaan risiko bencana yang melibatkan secara aktif masyarakat yang berisiko dalam mengkaji, menganalisis, menangani, memantau dan mengevaluasi risiko bencana untuk mengurangi kerentanan dan meningkatkan kemampuannya (Perka BNPB No. 1 Tahun 2012 tentang Pedoman Umum Desa/Kelurahan Tangguh Bencana).

Kelompok Siaga Bencana telah ada sejak tahun sekitar tahun 2011 namun keberadaannya belum terlihat. Ada kelurahan yang kelompok Siaga Bencananya aktif dan ada juga yang vakum. Tahun 2017, Walikota Padang Mengeluarkan Instruksi Walikota Padang No. 800.83/BPBD-Pdg/II/2017 tentang Pembentukan/Aktifasi KSB Kelurahan sebagai upaya untuk mengaktifkan kembali Kelompok Siaga Bencana yang Sebelum telah terbentuk namun tidak melaksanakan kegiatan penanggulangan bencana atau vakum. Serta instruksi ini juga di tujukan untuk Kelurahan yang belum memiliki Kelompok Siaga Bencana untuk segera membentuk. Kelompok siaga bencana dalam menjalankan aktifitasnya belum memiliki aturan atau alur kerja yang jelas sehingga kerja Kelompok Siaga Bencana lebih bersifat bykasus, artinya jika ada kejadian, ataupun kegiatan-kegiatan yang melibatkan mereka disitulah mereka ada.
Sehingga untuk mengevaluasi nya sulit dilakukan.

Penelitian ini bertujuan untuk mendeskripsikan faktor yang mempengaruhi peranan yang di lakukan oleh Kelompok Siaga Bencana untuk mewujudkan kesiapsiagaan masyarakat di Kota Padang khususnya Kecamatan Padang Utara.

\section{Tinjauan Kepustakaan Konsep Peranan}

Raho (2016) mengartikan peran sebagai suatu tingkah laku yang diharapkan oleh masyarakat dari seorang individu yang memiliki status atau menempati posisi tertentu. Kemudian Ralph Linton dalam Raho (2016) mengartikan peran sebagai ekspresi dinamis dari status. Seorang individu yang menduduki status tertentu akan melaksanakan peran tertentu. Lavinson dalam Abdulsyani (2012), menyebutkan peranan mencakup tiga hal yaitu:

a. Peranan meliputi norma - norma yang dihubungkan dengan posisi atau tempat seseorang dalam masyarakat. Hal ini berkaitan denga peraturanperaturan yang membimbing seseorang dalam kehidupan.

b. Peranan adalah suatu konsep perihal apa yang dilakukan oleh individu dalam masyarakat sebagai organisasi.

c. Peranan juga dapat dikatakan sebagai perikelakuan individu yang penting bagi struktur sosial masyarakat.

$$
\text { Johnson \& Johnson (2012) }
$$

mengartikan peran sebagai sejumlah harapan untuk melakukan tindakan yang layak dari seorang anggota dalam sauatu posisi dengan posisi lain yang berhubungan. Dalam menjalankan peran setiap anggota saling berinteraksi agar tujuan kelompok dapat tercapai.

Muhardina Jelita, Zikri Alhadi |45 


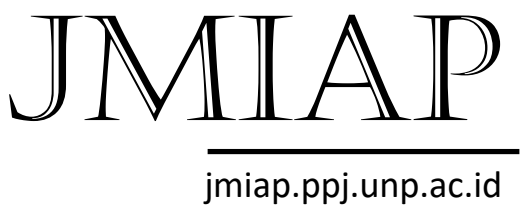

JURNAL ILMU ADMINISTRASI PUBLIK

Email : jianfis.unp@gmail.com Vol. 1 No. 1 Tahun 2018

Kadangkala peran yang satu saling melengkapi dengan peran yang lain sehingga suatu peran tidak tercapai tanpa adanya peran yang lain. Harapan dalam menjalankan suatu peran termasuk hak dan kewajiban, kewajiban dalam suatu peran adalah hak untuk peran yang lainnya. Selanjutnya Veitzal Rivai (2004), mengartikan peranan sebagai perilaku yang diatur dan diharapkan seseorang dalam posisi tertentu.

Ada tiga bentuk peranan dalam masyarakat, yaitu :

a. sebagai mediator

Organisasi sebagai wakil masyarakat dan sebagai pengantar dalam menjalin kerjasama yang harmonis serta mengakomodasi kepentingan -kepentingan masyarakat kepada pihak-pihak terkait.

b. sebagai motivator

Organisasi sebagai pemberi dan penanggungjawab utuk meningkatkan sumber daya anggotanya sebagai modal bagi kemajuan dimasa depan.

c. sebagai fasilitator

Organisasi bertanggungjawab membantu anggotanya agar mampu menangani tekanan situasional maupun tradisional.

\section{Konsep Bencana}

Bencana adalah gangguan serius terhadap fungsi masyarakat yang mengakibatkan kerugian manusia, material, atau lingkungan yang luas melebihi kemampuan masyarakat yang terkena dampak dan harus mereka hadapi menggunakan sumber daya yang ada pada mereka (Asian Disaster Reduction Centre (2003) dan the United Nations (1992) dalam Kusumasari (2014). Routela, (2006 dalam Kusumasari, 2014) menekankan bahwa bencana merupakan sebuah kondisi kerusakan dan goncangan yang menyebabkan kehancuran pada struktur sosial serta populasi yang terkena dampak bencana tidak mampu mengatasi peristiwa tersebut dan membutuhkan bantuan pihak luar. Selanjutnya carter (1991 dalam Kusumasari, 2014) mengidentifikasikan ada empat karakteristik yang membedakan bencana dengan kejadian lainnya yang terjadi dalam kehidupan manusia. Pertama, fokus pada kekacauan, yaitu dalam hal kecepatan serangan, prediksi dan luasnya. Kedua, kaitan efek atau dampak dari kejadian tersebut terhadap manusia, misalnya kematian, cedera, atau penyakit, dan menyebabkan penderitaan. Ketiga, kerusakan atau kehancuran infrastruktur, seperti fasilitas penyangga hidup serta komunikasi dan layanan penting. Keempat, adanya kebutuhan terhadap bantuan kemanusiaan, seperti perawatan kesehatan, tempat tinggal, makan, pakaian, dan kebutuhan sosial lainnya. Kemudian dalam Undang-Undang No 24 tahun 2007 Pasal 1 ayat (1), disebutkan bahwa bencana merupakan peristiwa atau rangkaian peristiwa yang mengancam dan mengganggu kehidupan dan penghidupan masyarakat yang disebabkan, baik oleh faktor alam dan/atau faktor nonalam maupun faktor manusia sehingga mengakibatkan timbulnya korban jiwa manusia, kerusakan lingkungan, kerugian harta benda, dan dampak psikologis.

Bencana dikategorikan kedalam tiga jenis, yaitu bencana alam, bencana buatan manusia, dan hibrida. Bencana alam merupakan kejadian bencana akibat dari bahaya alam yang mungkin merupakan hasil dari dalam (di bawah permukaan 


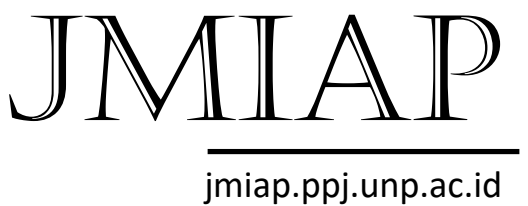

jmiap.ppj.unp.ac.id
JURNAL ILMU ADMINISTRASI PUBLIK

Email : jianfis.unp@gmail.com Vol. 1 No. 1 Tahun 2018 bumi), dari luar/eksternal (topogrfi), cuaca (meteorologi/hidrologi), dan fenomena biologis. Bencana hasil buatan manusia adalah kejadian bencana yang merupakan hasil keputusan atau perbuatan manusia. Bencana buatan manusia yang sacara tibatiba terjadi meliputi runtuhnya struktur bangunan, dan tambang yang terjadi dengan sendirinya, tanpa ada paksaan atau pengaruh dari luar. Bencana hibrida muncul dari keterkaitan antara hubungan antropogenik (buatan manusia) dan kejadian alam. Contoh dari bencana hibrida adalah menyebarkan penyakit penyakit dari masyarakat yang terkena wabah kepada masyarakat yang tidak memiliki sistem kekebalan tubuh alami, hancurnya hutan belantara yang menyebabkan erosi tanah, dan adanya polusi laut akibat dari pembuangan minyak atau produk-produk bahan kimia secara sengaja. (Kusumasari, 2014).

Undang-Undang No 24 tahun 2007 menyebutkan ada 3 jenis bencana yaitu :

a. Bencana Alam adalah bencana yang diakibatkan oleh peristiwa atau serangkaian peristiwa yang disebabkan oleh alam antara lain berupa gempa bumi, tsunami, gunung meletus, banjir, kekeringan, angin topan, dan tanah longsor.

b. Bencana Non-alam adalah bencana yang diakibatkan oleh peristiwa atau rangkaian peristiwa nonalam yang antara lain berupa gagal teknologi, gagal modernisasi, epidemi, dan wabah penyakit

c. Bencana Sosial adalah bencana yang diakibatkan oleh peristiwa atau serangkaian peristiwa yang diakibatkan oleh manusia yang meliputi konflik sosial antarkelompok atau antarkomunitas masyarakat, dan teror.

\section{Konsep Kesiapsiagaan}

Kesiapsiagaan dalam UU NO 24

tahun 2007 tentang Penanggulangan Bencana merupakan serangkaian kegiatan yang dilakukan untuk mengantisipasi bencana melalui pengorganisasian serta melalui langkah yang tepat guna dan berdaya guna. Nick Carter (dalam Deny Hidayati, 2006) mengemukakan kesiapsiagaan dari suatu pemerintahan, suatu kelompok masyarakat atau individu merupakan tindakan-tindakan yang memungkinkan pemerintahan, organisasiorganisasi, masyarakat, komunitas dan individu untuk mampu menanggapi suatu situasi bencana secara cepat dan tepat guna. Tindakan kesiapsiagaan meliputi kegatan penyusunan rencana penanggulangan bencana, pemeliharaan sumber daya dan pelatihan personil. Gregg dalam Dodon (2013) mengatakan menjelaskan bahwa kesiapsiagaan bertujuan untuk meminimalkan efek samping bahaya melalui tindakan pencegahan yang efektif, tepat waktu, memadai, efesiensi untuk tindakan tanggap darurat dan bantuan saat bencana. Kesipasiagaan bertujuan untuk mengantisipasi masalah dan sumber daya tempat yang yang diperlukan untuk memberikan respons secara efektif sebelum bencana terjadi (Kreps, 1991; Mileti, 1991 dalam Kusumasari, 2014).

\section{LIPI-UNESCO/ISDR}

(2006)

melakukan pengembangan framework kajian kesiapsiagaan masyarakat untuk mengantisipasi bencana alam yang dimulai dengan melakukan kajian terhadap faktorfaktor kritis yang mempunyai pengaruh signifikan terhadap masyarakat dalam menghadapi bencana alam. Dalam kajian itu terdapat 5 faktor kritis kesiapsiagaan untuk mengantisipasi bencana alam, terutama gempa bumi dan tsunami, yang 


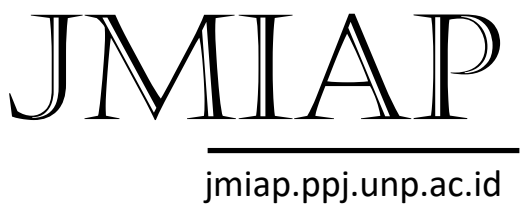

kemudian disepakati menjadi parameter dalam assessment framework yaitu:

1) Pengetahuan dan sikap terhadap resiko bencana

Pengetahuan merupakan kunci utama kesiapsiagaan pengetahuan yang dimiliki dapat mempengaruhi sikap dan kepedulian masyarakat untuk siap dan siaga dalam mengatasi bencana, terutama masyarakat yang bertempat tinggal di daerah rawan bencana. Parameter ini dijabarkan kedalam variabel :

(a)Pemahaman tentang bencana alam

(b)Pemahaman tentang kerentanan linkungan

(c)Pemahaman tentang ketentanan bangunan fisik dan fasilitas-fasilitas penting untuk keadaan darurat bencana

(d)Sikap dan kepedulian terhadap resiko bencana

2) Kebijakan dan panduan

Kebijakan kesiapsiagaan bencana alam sangat penting dan merupakan upaya konkrit untuk melaksanakan kegiatan siaga bencana. Kebiajakan yang signifikan berpengaruh terhadap kesiapsiagaan, meliputi pendidikan publik, emergency planning, sistem peringatan bencana dan mobilisasi sumberdaya, pendanaan, organisasi pengelola, SDM, dan fasilitas-fasilitas penting dalam kondisi darurat. Kebijakan-kebijakan tersebut dituangkan dalam berbagai bentuk seperti SK atau Perda yang disertai dengan job description yang jelas. Agar kebijakan dapat diimplementasikan dengan optimal, maka dibutuhkan panduan operasionalnya. Parameter ini
Email : jianfis.unp@gmail.com Vol. 1 No. 1 Tahun 2018 dijabarkan kedalam kedalam tiga variabel :

(a)Jenis-jenis kebijakan kesiapsiagaan untuk mengantisipasi bencana alam, seperti organisasi pengelolabencana, rencana aksi untuk tanggap darurat, sistem peringatan bencana, pendidikan masyarakat dan alokasi bencana

(b)Peraturan-peraturan yang relevan seperti perda dan SK

(c)Panduan-panduan yang relevan

3) Rencana untuk kegiatan darurat bencana

Rencana merupakan bagian penting dalam kesiapsiagaan, terutama berkaitan dengan evakuasi, pertolongan, dan penyelamatan, agar korban dapat diminimalkan. Parameter ini dijabarkan kedalam delapan variabel :

(a)Organisassi pengelola bencana termasuk kesiapsiagaan bencana,

(b)Rencana evakuasi, termasuk lokasi dan tempat evakuas, peta, jalur, dan rambu-rambu evakuasi,

(c)Posko bencana dan prosedur tetap (protap) pelaksanaan

(d)Rencana pertolongan pertama, penyelamatan, keselamatan dan keamanan, ketika terjadi bencana

(e)Rencana pemenuhan kebutuhan dasar, termasuk makanan, minuman, pakaian, tempat/tenda pengungsian, air bersih, MCK dan sanitasi lingkungan, kesehatan dan informasi tentang bencana dan korban.

(f) Peralatan dan perlengkapan evakuasi

(g)Fasilitas-fasilitas penting untuk keadaan darurat (rumah sakit/posko kesehatan, pemadam kebakaran, 
PDAM, TEKOM, PLN, Pelabuhan dan bandara)

(h)Latihan dan simulasi evakuasi

4) Sistem peringatan bencana

Sistem ini meliputi tanda peringatan dan distribusi informasi akan terjadinya bencana. Dengan adanya sitem peringatan ini masyarakat dapat melakukan tindakan yang tepat untuk mengurangi korban jiwa. Harta benda, atau kerusakan lingkungan. Untuk itu diperlukan adanya latihan dan simulasi. Parameter ini dijabarkan kedalam tiga variabel :

(a) Sistem peringatan bencana secara tradisional, yang telah berkembang/berlaku secara umum turun temurun, dan/atau kesepakatan lokal

(b) Sistem peringatan bencana berbasis teknologi yang bersumber dari pemerintah, termasuk instalasi peralatan, tanda peringatan, diseminasi informasi peringatan dan mekanismenya

(c) Latihan dan simulasi

5) Kemampuan untuk memobilisasi sumber daya

Sumber daya yang tersedia, baik sumber daya manusia, maupun pendanaan, sarana dan prasarana penting untuk kegiatan darurat merupakan potensi yang dapat mendukung atau sebaliknya menjadi kendala dalam kesiapsiagaan bencana. Maka dari itu mobilisasi sumber daya menjadi menjadi faktor yang krusial. Parameter ini dijabarkan kedalam variabel berikut :

(a) Pengaturan kelembagaan dan sistem komando (b) Sumber daya manusia termasuk ketersediaan personel dan relawan, keterampilan, dan keahlian

(c) Bimbingan teknis dan penyediaan bahan dan materi kesiapsiagaan bencana alam

(d) Mobilisasi dana

(e) Koordinasi dan komunikasi antar stakeholders yang terlibat dalam kesiapsiagaan bencana

(f) Pemantauan dan evaluasi kegiatan kesiapsiagaan bencana.

\section{Metode}

Penelitian ini menggunakan pendekatan kualitatif deskriptif. Penelitaian ini dilakukan di Kecamatan Padang Utara Kota Padang. Data yang digunakan dalam penelitian ini adalah data primer dan data sekuder. Data dalam penelitian ini diperoleh melalui hasil wawancara dan studi dokumentasi. Informan dalam penelitian ini ditentukan dengan menggunakan metode pusrposive dan insidental.

Penelitian ini melibatkan informan antara lain BPBD Kota Padang, Pihak Kelurahan, Pihak Kecamatan, Kelompok Siaga Bencana Kelurahan, Kelompok Siaga Bencana Kecamatan, masyarakat dan LSM. Analisis data diawali dengan melakukan reduksi data, penyajian data, penarikan kesimpulan dan verifikasi. Uji keabsahan data dalam penelitian ini menggunakan teknik triangulasi.

\section{Hasil Penelitan dan Pembahasan}

Kusumasari (2014) memandang perkumpulan masyarakat diperlukan karena masyarkat lokal mengetahui kebutuhan yang terbaik bagi mereka. Muhardina Jelita, Zikri Alhadi | $\mathbf{4 9}$ 


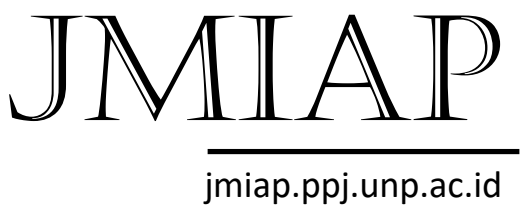

JURNAL ILMU ADMINISTRASI PUBLIK

Email : jianfis.unp@gmail.com Vol. 1 No. 1 Tahun 2018
Dalam mewujudkan kesiapsiagaan masyarakat di kecamatan Padang Utara, peran KSB sangat penting karena mereka berada di wilayah administratif terendah dan berada di tengah-tengah masyarakat. Suatu upaya yang dilakukan untuk memberikan peran yang lebih besar bagi masyarakat diciptakan suatu pendekatan berbasis masyarakat pada tahun 2005 untuk mendorong dan mengundang partisipasi yang lebih aktif dari anggota masyarakat agar dapat menyampaikan ide-ide dalam perencanaan, pelaksanaan, dan evaluasi program-program kesiapan, kesiapsiagaan, darurat, respons, dan pemulihan (Disaster Preparedness Centre Asia, 2008 dalam Kusumasari, 2014). Sehingga mereka yang diharapkan paling memahami kondisi masyarakatnya di wilayah mereka berada. Dalam Perka BNPB No 17 Tahun 2011 tentang Pedoman Relawan Penanggulangan Bencana, Pada saat pra bencana Kelompok Siaga Bencana berperan dalam kegiatan pencegahan, mitigasi dan kesiapsiagaan. Dalam membangun kesiapsiagaan masyarakat KSB berperan dalam memberikan sosialisasi dan edukasi kepada masyarakat. Sosialisasi yang diberikan berupa simulasisimulasi. Edukasi yang diberikan oleh kelompok siaga bencana kapada masyarakat berupa penyuluhanpenyuluhan ke rumah-rumah dan sekolahsekolah yang ada di wilayah masingmasing. Kemudian Kusumasari (2014) mengatakan bahwa dalam mengelola bencana diperlukan tersedianya penyebaran informasi kepada seluruh masyarakat, karena dalam banyak kasus informasi tentang bahaya yang mengancam masyarakat jarang disebarluaskan kepada masyarakat. Informasi lainnya yang diperlukan oleh masyarakat adalah tentang cara menjaga keamanan dan ini bisa disertakan dalam kurukulum sekolah, selain itu juga diperlukan tersedianya hotline agar masyarakat dapat menghubungi jika terjadi bencana.

Dalam menjalankan perannya untuk mewujudkan kesiapsiagaan masyarakat, dipengaruhi oleh beberapa faktor baik faktor pendorong maupun faktor penghambat. Faktor yang mempengaruhi peranan Kelompok Siaga Bencana tersebut adalah sebagai berikut :

\section{Faktor Pendorong}

Kelompok Siaga Bencana dalam menjalankan perannya pada saat pra bencana didorong oleh, kondisi geografis wilayah kecamatan Padang Utara yang merupakan zona merah bencana terutama gempa bumi dan tsunami; adanya program dari pemerintah baik itu dari tingkat global hingga daerah, memiliki program peningkatan kesiapsiagaan; kemudian aspek terpernting nya adalah adanya kemauan dari masyarakat sendiri dengan jiwa sosial yang di miliki untuk bersama sama membangun masyarakat.

a. Kondisi geografis wilayah

Secara geografis wilayah kecamatan Padang Utara yang merupakan salah satu zona merah bencana terutama gempa bumi dan tsunami menjadi salah satu faktor yang membuat KSB ada, membantu warga yang terkena musibah bencana. Potensi bencana yang terjadi di Kecamatan Padang Utara dilihat berdasarkan Dokumen Kajian Risiko Bencana Kota Padang Sumatera Barat Tahun 2014-2018 dapat dilihat bahwa potensi bencana tergolong pada bahaya kelas tinggi untuk jenis bencana Banjir dengan indeks bahaya 0,818, Tsunami dengan 
indeks bahaya 0,905, gelombang ekstrim dan abrasi pantai dengan indeks bahaya 0,816, dan gagal teknologi dengan indeks bahaya 0,704 . Untuk jenis bencana yang tergolong pada kelas sedang adalah bencana gempa bumi dengan indeks bahaya 0,550, tanah longsor dengan indeks bahaya 0,583 , kebakaran hutan dan lahan dengan indeks bahaya 0,385, dan bencana kekeringan dengan indeks bahaya 0,666. Sementara itu untuk jenis bencana epidemi dan wabah penyakit dengan indeks bahaya 0,333 potensinya tergolong pada kelas rendah (diolah dari Dokumen Kajian Resiko Bencana Kota Padang Sumatera Barat 2014-2018).

Selain itu tingkat kerentanan masyarakat Kecamatan Padang Utara dilihat juga dari jumlah penduduk yang terpapar dan kelompok masyarakat rentan berada pada kelas tinggi dengan indeks 0,866 untuk jenis bencana Banjir dengan jumlah penduduk terpapar 65.662 jiwa; gempa bumi dengan jumlah penduduk terpapar 68.480 jiwa; tsunami jumlah penduduk terpapar 98.119 jiwa; cuaca ekstrim jumlah penduduk terpapar 69.491 jiwa; gelombang ekstrim dan abrasi jumlah penduduk terpapar 36.119 jiwa; kebakaran hutan dan lahan jumla $\mathrm{h}$ penduduk terpapar 66.447 jiwa; epidemi dan wabah penyakit jumlah penduduk terpapar 69,512 jiwa; kekeringan jumlah penduduk terpapar 69.151 jiwa; dan gagal teknologi jumlah penduduk terpapar 69.751 jiwa. Sedangkan untuk jenis bencana tanah longsor berada pada kelas sedang dengan indeks penduduk terpapar 0,466 dengan jumlah penduduk terpapar 59 jiwa (diolah dari Dokumen Kajian Resiko Bencana Kota Padang Sumatera Barat 2014-2018).

Bencana ini juga menimbukan banyak kerugian baik itu kerugian ekonomi maupun kerusakan lingkungan. Kerugian rupiah yang diakibatkan oleh bencana, yakni kerugian fisik dan ekonomi untuk wilayah kecamatan Padang Utara berada pada kelas Tinggi untuk bencana kekeringan dengan indeks 1,000. Sedangkan yang berada pada kelasa sedang ada beberapa jenis bencana diantara nya bencana beanjir dengan indeks 0, 400; gempa bumi dengan indeks 0,480 ; tsunami dengan indeks 0,395; cuaca ekstrim dengan indeks 0,480; gelombang ekstrim dan abrasi dengan indeks 0,352 ; epidemi dan wabah penyakit dengan indeks 0,400; gagal teknologi. Tanah longsor dengan indeks 0,191 dan kebakarakan hutan \& lahan dengan indeks 0,260 berada pada kelas rendah. Selanjutnya kerusakan lingkungan yang di akibatkan oleh terjadinya bencana berada pada kelas sedang untuk beberapa je nis bencana yaitu banjir dengan indeks 0,357 ; tsunami dengan indeks 0,443; gelombang ekstrim dan abrasi dengan indeks 0,441; kebakaran hutan dan lahan dengan indeks 0,357; epidemi dan wabah penyakit dengan indeks 0,357 ; dan kekeringan dengan indeks 0,381. dan tergolong rendah untuk bencana tanah longsor dan gagal teknologi.

Oleh karena itu, Pemerintah berupaya untuk meminimalkan kerugian dan risiko yang di timbukan jika bencana terjadi. Pemerintah Daerah berupaya meminimalkan 
adanya nya korban jiwa pada setiap kejadian bencana. Salah satu upaya tersebut dengan meningkatkan kesiapsiagaan di semua tingkat. Upaya meningkatkan kesiapsiagaan di tingkat masyarakat tidak mungkin hanya bisa dijangkau oleh SDM yang dimiliki oleh BPBD Kota Padang sehingga adanya kelompok-kelompok relawan yang ada di tingkat masyrakat sangat membantu kerja BPBD dalam penanggulangan bencana.

b. Adanya Program Pemerintah

Adanya Kelompok Siaga

Bencana tak lepas dari adanya program yang lah direncanakan oleh pemerintah, baik secara gobal, nasional maupun di tingkat daerah. Program program peningkatan kapasitas untuk diharapkan dapat membangun kesiapsiagaan di dalam menghadapi bencana dan mengurangi potensi korban akibat terjadinya bencana. Pemerintah juga mencanangkan program untuk mengantisipasi risiko bencana. melalui program Padang Kota Cerdas Bencana. Outcome yang ingin dicapai dalam program Padang Kota Cerdas bencana adalah terbentuknya Kelurahan Cerdas Bencana, Keluarga Cerdas Bencana, Sekolah Cerdas Bencana, Kampus Cerdas Bencana, Tempat Les Cerdas Bencana, Rumah Sakit Cerdas Bencana, Rumah Ibadah Cerdas Bencana, Pasar Cerdas Bencana, Mall Cerdas Bencana dan Hotel Cerdas Bencana. Terbentuk nya kelurahan cerdas bencana dan Keluarga Cerdas Bencana melibatkan peran penting dari Kelompok Siaga Bencana sebagai unsur yang berada paling dekat dengan masyarakat di masing-masing kelurahan. c. Adanya Nilai-Nilai Kemanusiaan

Kelompok Siaga Bencana merupakan relawan penanggulangan bencana yang berada di tingkat masyarakat. Adanya KSB tidak lepas dari adanya msyarakat yang memiliki jiwa sosial tinggi sehingga bisa memberikan sebagian waktunya untuk melakukan kegiatan sosial. KSB bekerja membantu masyarakat untuk mendapatkan informasi-informasi tentang bencana yang terjadi di daerah mereka. Anggota KSB pada dasarnya ada karena niat baik, karena orangorang yang tergabung dalam kelompok siaga bencana tidak mendapatkan gaji. Mereka bekarja sebagai bentuk pengabdian. Oleh karena itu orangorang yang tergabung dalam KSB secara jumlah tidaklah banyak rata-rata hanya 20 orang bahkan ada juga yang hanya sebanyak 15 orang. Namun anggota yang tergabung dalam kepengurusan tidak semua yang aktif. Tanpa adanyanya jiwa sosial kemanuasian yang dimiliki oleh anggota KSB, maka Kelompok Siaga Bencana tidak mungkin terbentuk. Kelompok Siaga Bencana merupakan kelompok relawan kebencanaan yang memiliki konsep kerjasama dengan tulus dan ikhlas tanpa mengharapkan imbalan.

2. Faktor Penghambat

Penulis mengidentifikasi beberapa hal yang menjadi faktor penghambat bagi KSB dalam menjalankan perannya antara lain :

1) Sarana dan Prasarana Penunjang Kegiatan

Sarana dan prasarana merupakan faktor penunjang kegiatan KSB. Sarana dan Prasarana tersebut dapat berupa Handy Talky 


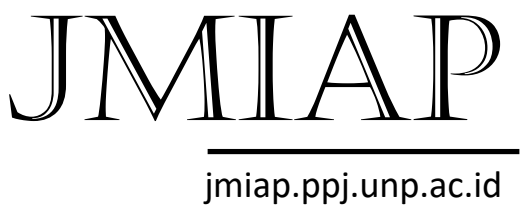

(HT), radio rig, dan lain-lain. Namun KSB yang ada di masing-masing kelurahan yang ada di kecamatan Padang Utara, tidak memiliki sarana dan prasana tersebut.

2) Tidak adanya dana Operasional kegiatan

Masalah utama yang dialami pemerintah dalam daerah dalam penanngulangan bencana adalah masalah anggaran (Kusumasari,2014). Kelompok Siaga Bencana merupakan kelompok di tingkat masyarakat yang bekerja secara sukarela atau yang disebut juga relawan penanggulangan bencana. Namun hal ini juga bertolak belakang dengan kondisi anggota KSB itu sendiri berasal dari latar belakang berbeda dan tidak semuanya memiliki penghasilan tetap. Sehingga KSB menjadi tidak aktif dan tidak memiliki kegiatan dan keberadaannya pun tidak terlihat.

3) Kurangnya partisipasi anggota KSB dalam menjalankan tugasnya

KSB merupakan kelompok relawan penanggulangan bencana di tigkat masyarakat. Anggota KSB terdiri dari berbagai latar belakang pendidikan, pekerjaan dan lainnya yang beraneka ragam. Namun fakta di lapangan bahwa tidak aktivnya KSB dalam menjalankan kegiatan nya dikarenakan kurangnya partisipasi anggota. Seperti KSB yang ada di kelurahan Air Tawar Barat, KSB sudah ada sejak sekitar tahun 2012 namun dalam kepengurusannya vakum. Sejak kepengurusan yang baru di tahun 2018 KSB belum pernah mengadakan pertemuan-pertemuan karena kurang nya partisipaai
JURNAL ILMU ADMINISTRASI PUBLIK

Email : jianfis.unp@gmail.com Vol. 1 No. 1 Tahun 2018

anggota. Begitu juga dengan KSB yang ada di ATT yang kurang aktif dalam kegiatan pra-bencana. Kelompok siaga bencana menjalankan tanggungjawab kalau ada bencana yang menimpa masyarakat.

4) Sulitnya mengubah paradigma masyarakat terhadap bencana.

Dalam melaksanakan sosialisasi serta edukasi anggota KSB tidak selalu diterima di tengah masyarakat, masih ada juga masyarakat yang tidak peduli dan tidak menerima kehadiran anggota KSB jika melakukan sosialisasi. Kusumsari(2014) mengatakan bahwa bagi sebagian orang bencana masih dipandang sebagai peristiwa langka dan merupakan hukuman dari Tuhan.

\section{Kesimpulan}

Kelompok Siaga Bencana di kecamatan Padang Utara berperan dalam memberikan sosialisasi dan edukasi kepada masyarakat. Berbagai faktor mempengaruhi KSB dalam menjalankan perannya, diantaranya adalah :

a. Faktor Pendorong, beberapa hal yang mendorong KSB memiliki peran dalam penanggulangan bencana saat pra bencana di Kecamatan Padang Utara adalah :

1) Kondisi geografis serta monografi kecamatan Padang Utara yang merupakan daerah bencana seperti banjir, abrasi pantai, serta termasuk zona merah bencana gempa bumi dan tsunami

2) Adanya program pemerintah, peningkatan kesiapsiagan untuk menghadapi bencana 


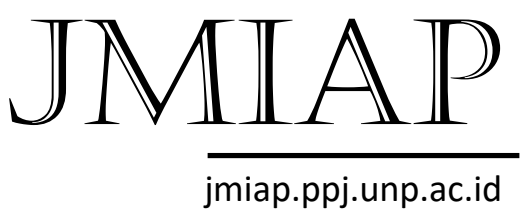

JURNAL ILMU ADMINISTRASI PUBLIK

Email : jianfis.unp@gmail.com Vol. 1 No. 1 Tahun 2018
melibatkan peran aktif masyarakat.
3) Adanya jiwa sosial kemanusiaan dalam diri anggota KSB

b. Faktor Penghambat, beberapa hal yang menjadi kendala KSB dalam menjalankan perannya adalah :

1) Terbatasnya sarana dan prasarana penunjang kegiatan KSB.

2) Tidak adanya dana operasional KSB.

3) Kurang nya partisipasi/ kepedulian sebagian anggota KSB.

4) Sulitnya mengubah paradigma masyarakat terhadap bencana.

\section{Daftar Pustaka \\ Buku}

Abdulsyani. 2012. Sosiologi : Skematika, Teori, dan Terapan. Jakarta : Bumi Aksara

Johnson, David W. \& Johnson, Frank P. 2012. Dinamika Kelompok: Teori Dan Keterampilan. Edisi Kesembilan. Jakarta : Indeks.

Kusumasari, Bevaola. 2014. Manajemen Bencana dan Kapabilitas Pemerintah Lokal. Yogyakarta : Gava Media

Nurjannah, dkk. 2013. Manajemen Bencana. Bandung : Alfabeta.

Raho, Bernard. 2016. Sosiologi.

Yogyakarta : Ledalero

\section{Atikel/Jurnal}

Alhadi, Zikri \& Samita, Siska. 2014. "Kesiapsiagaan Masyarakat Kota Padang Dalam Menghadapi Resiko Bencana Gempa Dan Tsunami Berbasis Kearifan Lokal (Studi Kesiapsiagaan Terhadap Resiko Bencana)". Jurnal Humanus Vol. XIII No.2 Th. 2014.
Dodon. 2013. "Indikator Dan Perilaku Kesiapsiagaan Masyarakat Di Permukiman Padat Penduduk Dalam Antisipasi Berbagai Fase Bencana Banjir”. Jurnal Perencanaan Wilayah dan Kota, Vol. 24 No. 2, Agustus 2013, hlm.125 - 140

Hidayati, Deni. 2008. “ Kesiapsiagaan Masyarakat: Paradigma Baru Penanggulangan Bencana Alam di INdonesia". Jurnal Kependudukan Indonesia Vol. III, No. 1, 2008.

Oktiari, Dian \& Manurun, Sudomo. 2010. “ Model Geospasial Potensi Kerentanan Tsunami Kota Padang". Jurnal Meteorologi dan Geofisika Vol, II No.2-November 2010, Hal 140-146

Tim Kajian LIPI-UNESCO/ISDR. 2006. "Kajian Kesiapsiagaan Masyarakat Dalam mengantisipasi Bencana Gempa Bumi dan Tsunami

\section{Dokumen Resmi}

Dokumen Kajian Resiko Bencana Kota Padang Sumatera Barat 2014 - 2018

Dokumen Rencana Penanggulangan Bencana Kota Padang 2014-2019

Pemerintah Kota Padang. 2017.Gran Design Padang Kota Cerdas Bencana

Peraturan Kepala BNPB No 1 Tahun 2012 Tentang Pedoman Umum Desa/Kelurahan Tangguh Bencana

Peraturan Kepala BNPB NO 17 tahun 2011 tentang Pedoman Relawan Penaggulangan Bencana

Undang-Undang No 24 Tahun 2007 Tentang Penanggulangan Bencana

\section{Internet}

WorldBank Group. (2009). Ringkasan Eksekutif. Sumber: 
JMIAP
JURNAL ILMU ADMINISTRASI PUBLIK

Email : jianfis.unp@gmail.com Vol. 1 No. 1 Tahun 2018

http://siteresources.worldbank.org/ diakses 23 Maret 2018 